\title{
AGING PROCESS IN CHROMATIN OF ANIMALS*
}

\author{
Maciej Wnuk ${ }^{1,2}$, Monika Bugno-Poniewierska ${ }^{1,3}$, Anna Lewińska ${ }^{4}$, \\ Bernadetta Oklejewicz ${ }^{1,2}$, Tomasz Ząbek ${ }^{3}$, Ewa Słota ${ }^{1,2}$ \\ ${ }^{1}$ Department of Genetics, University of Rzeszow, Rejtana 16C, 35-959 Rzeszów, Poland \\ ${ }^{2}$ Centre of Applied Biotechnology and Basic Sciences, University of Rzeszow, Sokołowska 26, \\ 36-100 Kolbuszowa, Poland \\ ${ }^{3}$ Laboratory of Genomics, National Research Institute of Animal Production, 32-083 Balice n. Kraków, \\ Poland \\ ${ }^{4}$ Department of Biochemistry and Cell Biology, University of Rzeszow, Rejtana 16C, \\ 35-959 Rzeszów, Poland
}

\begin{abstract}
The aging process is a variable, stochastic and pleiotropic phenomenon which is regulated by different environmental and genetic factors. The age-associated changes, which occur at the molecular and cellular levels and disturb biological homeostasis, may directly or indirectly contribute to aging, causing apoptosis or cellular senescence and consequently leading to the death of the organism. In this context, it is particularly interesting to observe changes in somatic cell chromatin. In the present paper, we summarized the knowledge on the biological aspects of aging with special consideration of age-related changes in chromatin like DNA damage, shortening telomeres or agerelated changes in methylation of DNA.
\end{abstract}

Key words: aging, heterochromatin, telomeres, DNA damage, rDNA

Aging is now viewed as a complex multifactorial process involving time-course changes occurring at the molecular and cellular levels that disturb biological homeostasis, and ultimately lead to the death of the organism. One of the many crucial questions faced by modern biology concerns the causes and factors determining the rate of aging (Sander et al., 2008). Recent findings provide conclusive evidence that underlying this phenomenon is a complex molecular mechanism (Funayama and Ishikawa, 2007; Altieri et al., 2008).

It is particularly interesting to observe changes in the genome of aging somatic cells. One of the manifestations of changes in the DNA of aging cells is an increase in mutations in the sequences of specific genes as well as an increase in overall genome instability leading to chromosomal aberrations (Altieri et al., 2008; Li et al., 2008). During the individual's lifetime, cells are exposed to many factors that may

\footnotetext{
*This work was supported by Grant No. N311 068937 from the State Commitee for Scientific Research of Poland.
} 
damage genetic material. In this context, most attention is focused on reactive oxygen species (Burhans and Weinberger, 2007; Gruber et al., 2008).

In mammalian cells, they are a natural byproduct of aerobic endogenous metabolism in mitochondria and peroxisomes. Hydroxyl radical, one of the most reactive oxygen species, is the main factor that causes damage to cells, their structure, and molecules, including DNA. DNA damage by endogenously generated reactive oxygen species results mainly in single-strand breaks (SSBs), less often in doublestrand breaks (DSBs). Meanwhile, exogenous factors such as ionizing radiation, UV radiation, and chemical mutagens cause mainly double-strand breaks (Wilson et al., 2003). DNA damage by reactive oxygen species may therefore result in chromosomal aberrations, cell cycle disturbances, cell death, and tumorigenesis, as well as being one of the causes of aging (Nussenzweig, 2007).

Observations in mice and other species provide unequivocal evidence for agerelated accumulation of mitochondrial damage as well as nuclear DNA damage (Sedelnikova et al., 2004). At the same time, studies investigating damage to both DNA strands indicate that two mechanisms that prevent this type of defects - nonhomologous end joining (NHEJ) and homologous recombination (HR) - play a role in the aging process. The complete or partial loss of the biological activity of proteins involved in any of the repair systems increases genome instability, which may accelerate the aging process (Li et al., 2008). NHEJ repair capacity was observed to undergo a decline in aging fibroblasts (Gorbunova et al., 2007). This is associated with $\mathrm{Ku}$ proteins, the expression level and DNA binding capacity of which depend on age and type of tissue (Um et al., 2003). Inconsistent evidence is available about peripheral blood lymphocytes, in which biological activity of Ku80 does not decrease with age, as is the case with other cell types. This draws attention to another mechanism responsible for repair of DSB type damage. Comparison of data obtained for neonatal and adult lymphocytes revealed an increase in the frequency of chromosomal aberrations, which was positively correlated to the occurrence of non-allelic homologous recombination (NAHR) in these cells (Flores et al., 2007). However, whether homologous recombination is involved in mammalian cell aging to a similar extent as repair involving non-homologous end joining is still unknown.

Our recent studies carried out on 80 horses divided into 3 age groups (juvenile, adult, old) showed that breed-independent and age-associated changes in genomic stability may contribute, at least in part, to the aging process in the horse (Wnuk et al., 2011). We observed a significantly increased level of positive TUNEL cells (both apoptotic and with DNA fragmentation), oxidative DNA damage (8-oxoG immunostaining), sister chromatid exchange and bleomycin-induced chromatid breaks in the old group compared to the adult group horses. However, we observed a negative correlation between micronuclei formation and age, which may be associated with damaged cells undergoing apoptosis, rather than expressing micronuclei (Wnuk et al., 2011).

The development of molecular biology techniques has directed increased attention to changes in sequences responsible for maintaining functional integrity of chromatin, such as telomeres, heterochromatin or rDNA. 
In vertebrates, telomeres consist of repeating sequences of TTAGGG and the associated proteins (Blackburn, 1991). Together with TRF proteins, guanine-rich telomeric sequences form loops, which stabilize chromosome ends. In most normal human somatic cells, telomeres are shortened by 50-200 bp with each replication round. When telomere length reaches a critical value of about 4-7 kbp, cell division is arrested (Allsopp et al., 1992; Levy et al., 1992). This phenomenon, known as the Hayflick limit, determines the replicative lifespan of cells and is probably the main mechanism that limits divisions of mammalian cells in vitro (Hayflick, 1998). Telomere length is also regulated by the associated proteins such as TRF1 and TRF2, as well as by telomerase reverse transcriptase, which adds TTAGGG repeats to chromosome ends (Smogorzewska and de Lange, 2004). The activity of this enzyme was found in vitro in some cell lines, cancer cells, germ cells, as well as in cells with increased division potential, such as stem cells and activated $\mathrm{T}$ and $\mathrm{B}$ lymphocytes (Hines et al., 2005). The loss of telomerase enzymatic activity leads to progressive telomere shortening, formation of chromosome fusions, and cell death (Blackburn, 2005). Research on telomerase activity and telomere shortening has shown that only cancer cells, sex cells and immortalized cell lines are able to prevent telomere shortening. Analyses with equine immortalized fibroblasts showed high levels of telomerase activity in this type of cells in contrast to primary cell cultures (Argyle et al., 2003). The other cell types mentioned above are only able to slow down this process. Lymphocyte studies provided evidence that disturbances of telomere structure due to telomere shortening with age can lower immune resistance (Weng et al., 1995; Hodes et al., 2002). This is associated with the role telomeres play in normal cells, ensuring the integrity and stability of chromosomes, and protecting them against degradation, fusion and inappropriate recombination (Bolzan and Bianchi, 2006). Damage to the telomeric region of the chromosome could be one of the factors that limit the cell's ability to divide, thus determining replicative lifespan. In human lymphocytes they have been implicated in increased frequency of chromosomal aberrations, and in cells of elderly people telomere shortening and the presence of large heterochromatin blocks were found to be positively correlated with the incidence of aberrations such as aneuploidy (Leach et al., 2004).

Of note is also the hypothesis that proteins associated with telomeres move to other loci, including rDNA, in mammalian somatic cells that normally lack telomerase activity, i.e. along with telomere shortening that progresses with advancing age. This may lead to the silencing of genes responsible for transcription of rRNA genes, among others (Guarente, 1997). The claim that telomere length is the main factor determining the cell's lifespan has recently been subject to criticism. In this context, it seems appropriate to investigate the inheritance of telomere length and to determine which protein or genetic factor is directly involved. Research studies have produced inconsistent or insufficient evidence on this subject (Kappei and LondonoVallejo, 2008).

The observed differences in telomere length may be associated with (1327)T/C polymorphism in the hTERT promoter gene (Matsubara et al., 2006), although not in all human populations (Nordfjall et al., 2007). Several reports have appeared in 
recent years on the inheritance of telomere length in humans and the effect of environmental factors (Huda et al., 2007; Gilley et al., 2008). They indicate that the rate of this phenomenon varies during the individual's lifetime. In neonates telomere length was found to shorten rapidly, in adults this process is slowed or completely undetectable, and in elderly people the rate of telomere shortening increases again. These observations motivate a search for differences in the rate of changes associated with telomere shortening (Frenck et al., 1998). Studies on telomerase activity in peripheral blood lymphocytes show that it is genetically regulated in response to myogenic stimulation of the cells and the activity of this enzyme increases after antigenic stimulation of the cells (Kosciolek and Rowley, 1998). Telomere shortening in lymphocytes is definitely a complex process that needs further analyses, including molecular cytogenetic tools.

Another group of researchers has pointed to heterochromatinization as a phenotypic, molecular marker of aging. According to the same authors, heterochromatinization progresses with age and results in decreased repair processes, increased chromosomal aberrations, and silencing of some genes (Lezhava, 2001). What is more, observations on the chromatin of aging mammalian cells revealed redistribution of heterochromatin from constitutive heterochromatin regions (such as pericentromeric or telomeric regions) to other euchromatic sites such as senescence-associated heterochromatin foci (SAHF). Epigenetic modification of SAHF foci may often lead to the formation of blocks of facultative heterochromatin (Narita et al., 2003). These regions are suspected to silence the expression of genes involved in skin cell proliferation (Herbig et al., 2006). Deheterochromatinization of pericentromeric or telomeric chromosome regions that contain constitutive heterochromatin was also observed in aging cells (Funayama et al., 2006; Zhang et al., 2007). Mouse cells lacking telomerase activity show telomere shortening and a simultaneous decrease in heterochromatinization compared to mouse cells with normal telomerase activity (Benetti et al., 2007).

Another region which can be a useful marker of the aging process is the nucleolar organizer region (NOR), where genes responsible for synthesis of $18 \mathrm{~S}, 5.8 \mathrm{~S}$ and $28 \mathrm{~S}$ rRNA are located. Ribosomal DNA is organized in tandem repeat units of variable length. Mammalian somatic cells may contain tens to hundreds of such repeat units per locus. In the horse, nucleolar organizer regions are located on three pairs of autosomal chromosomes, in the secondary constriction of the short arm of chromosome 1 and in pericentromeric regions of chromosome 28 and 31 (Świtoński et al., 1994; Słota et al., 2007). In addition, some researchers report the presence of an extra rDNA locus on chromosome pair 27 (Derjusheva et al., 1998). The main proteins of the transcription complex (UBF, SL1 and RNA pol I) remain associated with the nucleolar organizer region at mitosis (McStay and Grummt, 2008). Nucleolar organizer regions are identified by silver nitrate staining (Goodpasture and Bloom, 1975) and in situ hybridization (ISH), using specific rDNA probes (Johnson et al., 2002). Silver nitrate staining allows detecting transcriptionally active rDNA genes, while ISH detects all rDNA loci regardless of their transcriptional activity. It is assumed that AgNOR staining is the most effective procedure for detecting and determining the transcriptional activity of nucleolar organizer regions (Guillen et al., 2004). Tran- 
scriptional activity of rDNA, expressed as the number and size of silver deposits, is closely correlated to the physiological status of the cell (Hubbell, 1985).

Research on rDNA transcriptional activity in humans revealed a relationship between the number of silver deposits and age (Denton et al., 1981; Thomas and Mukherjee, 1996; Nakatani et al., 2007). An experiment with human submandibular glands showed that the number of silver deposits increases after birth, reaches a maximum at the age of 20-30 years, and decreases in senile age (Nakatani et al., 2007). Many studies have shown that the average number of chromosomes with silver deposits is much higher in infants less than 1 year of age than in elderly people aged 69 to 83 years (Buys et al., 1979; Das et al., 1986; Nakatani et al., 2007). This phenomenon is associated with reduced transcriptional activity due to rDNA loss (Johnson et al., 1975).

Studies on repression of NOR transcriptional activity in mammals suggest that nucleolar organizer regions are inactivated by at least three mechanisms: elimination of rDNA, methylation of rDNA, and gene silencing due to position effects induced by heterochromatin or telomeres (Guillen et al., 2004; Slota et al., 2007). Regulation of gene expression by methylation is an epigenetic mechanism that plays a crucial role in inactivation of NORs. Vertebrate DNA is often modified in $\mathrm{CpG}$ islands by a covalent bond of the methyl group into cytosine to form $\mathrm{m} 5 \mathrm{CpG}$ (Gruenbaum et al., 1981). Using restriction enzymes, Brock and Bird (1997) showed a mosaic pattern of $\mathrm{CpG}$ methylation of the repeat unit of human rDNA. The main part of the rDNA repeat unit can be methylated in most, if not all, vertebrates. Methylation is probably a fundamental mechanism that determines the absence of silver-staining proteins associated with the rDNA region. In rats, $\mathrm{CpG}$ methylation was mainly observed in enhancer and promoter regions of inactive rRNA gene copies. Using HpaII enzyme, a significant correlation was found between rDNA transcription activity and the activity of this enzyme (Stancheva et al., 1997).

In recent years, Grummt and co-workers published a number of papers on methylation-dependent silencing of rRNA genes (McStay and Grummt, 2008). The silencing model posits that TTF-1 repositions nucleosomes in the vicinity of the promoter. This process requires ATP-dependent nucleolar remodelling complex (NoRC). NoRC consists of two subunits: TIP5 (TTF-1 interacting protein 5) and SNF2 (ATP-dependent remodelling factor). At the same time, NoRC interacts with DNA methyltransferases (DNMT1, DNMT3b) and histone deacetylases (HDAC1). NoRC also mediates histone $\mathrm{H} 4$ deacetylation and de novo DNA methylation ( $\mathrm{Li}$ et al., 2005). NoRC silences rDNA transcription through histone modification and DNA methylation in the rDNA promoter fragment (Strohner et al., 2004). In addition, histone H3-lysine 9 (H3K9) methylation and subsequent binding of HP1 (heterochromatin protein 1) ultimately help to form a compact DNA structure (McStay and Grummt, 2008). This reduces the degree of histone acetylation and induces a more tightly packed chromatin structure, which is why UBF cannot be bound to the methylated promoter and cannot form an active RNA pol I transcription complex. Methylation disturbances in aging cells have created considerable interest among scientists. It was shown, among others, that total 5-methylcytosine content in cells decreases with age (Mays-Hoopes, 1989). This decrease is probably related to a de- 
crease in DNMT1 methyltransferase expression (Berletch et al., 2007). In addition, hypomethylation in aging cells is also observed in regions lying outside $\mathrm{CpG}$ islands. A similar phenomenon is often observed in cancer cells. In both propagation processes, hypomethylation is accompanied by increased incidence of chromosomal aberrations (Gaudet et al., 2003). At the same time, it was observed that certain DNA regions in aging cells can also be hypermethylated (Fraga and Esteller, 2007). It has been repeatedly demonstrated that suppressor genes in aging cells may undergo hypermethylation (Liu et al., 2003). Increasing methylation with age was observed in rDNA genes in mouse liver, spleen and brain tissues, as well as ribosomal gene cluster inactivation. The authors suggest that hypermetylation of rRNA genes is age associated, but not organ-specific (Swisshelm et al., 1990).

No data are available to suggest that similar processes occur in lymphocytic cells. The specific localization of eukaryotic loci of ribosomal DNA near heterochromatin blocks, centromeres or telomeres suggests that these sequences are not indifferent to the transcriptional activity of ribosomal genes. Long repeat sequences located in the proximity of rRNA genes may silence their activity, and the silencing of active genes by heterochromatin or telomere sequences is known as the position effect. Thus, the position effect may be another long-term mechanism that silences the transcriptional activity of rRNA genes. The position effect has been described in the chimpanzee, where it is associated with the presence of distal heterochromatin blocks near rDNA (Guillen et al., 2004). The highly condensed heterochromatin region inhibits rRNA gene transcription by blocking bindings of proteins to specific sequences that they identify. The determination of potential mechanisms causing a change in the level of transcriptional activity of nucleolar organizer regions in aging cells is of special importance with regard to evaluating the division potential of these cells as well as AgNOR size variants as chromosome markers.

In summary, little attention has been given in the literature to age-related changes in domestic animals. Therefore, today the great challenge for animal genetics is to gain knowledge on how age-related changes at the genomic and DNA level may influence reproductive and lifespan potential of domestic animals and to identify new molecular biomarkers of domestic animal aging.

\section{References}

A 11 s opp R.C., Vaziri H., Patters on C., Goldstein S., Younglai E.V., Futcher A.B., Gre i d e r C.W., H a r le y C.B. (1992). Telomere length predicts replicative capacity of human fibroblasts. Proc. Natl. Acad. Sci. U.S.A., 9: 10114-10118.

Altieri F., Grillo C., M a c er oni M., Ch i chi a relli S. (2008). DNA damage and repair: from molecular mechanisms to health implications. Antioxid Redox Signal, 10: 891-937.

Argyle D., E11s more V., Gault E.A., Munro A.F., Na sir L. (2003). Equine telomeres and telomerase in cellular immortalisation and ageing. Mech. Ageing Dev., 124: 759-764.

B enetti R., Garcia-Ca o M., B las c o M.A. (2007). Telomere length regulates the epigenetic status of mammalian telomeres and subtelomeres. Nat. Genet., 39: 243-250.

B e r l e t c h J.B., A n d rew s L.G., T o 11 e f s b o 1 T.O. (2007). A method to detect DNA methyltransferase I gene transcription in vitro in aging systems. Methods Mol. Biol., 371: 73-80. 
B l a c k b u r n E.H. (1991). Structure and function of telomeres. Nature, 350: 569-573.

B la ckburn E.H. (2005). Telomeres and telomerase: their mechanisms of action and the effects of altering their functions. FEBS Lett., 579: 859-862.

B ol zan A.D., B i a c h i M.S. (2006). Telomeres, interstitial telomeric repeat sequences, and chromosomal aberrations. Mutat. Res., 612: 189-214.

B r o c k G.J., B ird A. (1997). Mosaic methylation of the repeat unit of the human ribosomal RNA genes. Hum. Mol. Genet., 6: 451-456.

B urhans W.C., We in berger M. (2007). DNA replication stress, genome instability and aging. Nucleic Acids Res., 35: 7545-7556.

B u y s C.H., O s ing a J., A nders G.J. (1979). Age-dependent variability of ribosomal RNA-gene activity in man as determined from frequencies of silver staining nucleolus organizing regions on metaphase chromosomes of lymphocytes and fibroblasts. Mech. Ageing Dev., 11: 55-75.

D a s B.C., Rani R., Mitra A.B., Luthra U.K. (1986). The number of silver-staining NORs (rDNA) in lymphocytes of newborns and its relationship to human development. Mech. Ageing Dev., 36: 117-123.

D e n t o n T.E., L i e m S.L., C h e n g K.M., B a r r e t t J.V. (1981). The relationship between aging and ribosomal gene activity in humans as evidenced by silver staining. Mech. Ageing Dev., 15: 1-7.

Derjusheva S.E., Loginova J.A., P arada R., Chiria eva O.G., S mirnov A.F., J a s z c zak K. ( 1998). The comparative analysis of NOR polymorphism detected by FISH and Agstaining on horse chromosomes. Caryologica, 51: 1-11.

Flores M., Morales L., Gonzaga-Jauregui C., Dominguez-Vidana R., Zeped a C., Yanez O., Gutierrez M., Lemus T., Valle D., Avila M.C., Blanco D., Me dina-Ruiz S., Meza K., Ayala E., Garcia D., Bustos P., Gonzalez V., Girard L., Tus i e - Lun a T., D avila G., P a l a c i os R. (2007). Recurrent DNA inversion rearrangements in the human genome. Proc. Natl. Acad. Sci. U.S.A., 104: 6099-6106.

Frag a M.F., Es te 11 e r M. (2007). Epigenetics and aging: the targets and the marks. Trends Genet., 23: $413-418$.

Fren c k R.W. Jr., B l a c k burn E.H., S h a n n o n K.M. (1998). The rate of telomere sequence loss in human leukocytes varies with age. Proc. Natl. Acad. Sci. U.S.A., 95: 5607-5610.

F un y a ma R., I s hi kaw a F. (2007). Cellular senescence and chromatin structure. Chromosoma, 116: $431-440$.

F un a y ma R., S a ito M., T a n obe H., I sh ik aw a F. (2006). Loss of linker histone H1 in cellular senescence. J. Cell Biol., 175: 869-880.

Gaudet F., Hodgson J.G., Eden A., Jackson-Grusby L., Dausman J., Gray J.W., L e o nhardt H., J a e n is ch R. (2003). Induction of tumors in mice by genomic hypomethylation. Science., 300: 489-492.

Gilley D., Herbert B.S., Huda N., T an aka H., Reed T. (2008). Factors impacting human telomere homeostasis and age-related disease. Mech. Ageing Dev., 129: 27-34.

G o o d p a s t u r e C., B l o o m S.E. (1975). Visualization of nucleolar organizer regions in mammalian chromosomes using silver staining. Chromosoma, 53: 37-50.

Gorbunova V., S e lu a nov A., Ma o Z., Hin e C. (2007). Changes in DNA repair during aging. Nucleic Acids Res., 35: 7466-7474.

Gruber J., S c haffer S., Ha 11 iw e 11 B. (2008). The mitochondrial free radical theory of ageing where do we stand? Front Biosci., 13: 6554-6579.

Gruen baum Y., S te in R., Ce dar H., R a z in A. (1981). Methylation of CpG sequences in eukaryotic DNA. FEBS Lett., 124: 67-71.

Guarente L. (1997). Chromatin and ageing in yeast and in mammals. Ciba Found. Symp., 211: $104-111$.

G u illen A.K., Hir a i Y., T a n o u e T., H ir a i H. (2004). Transcriptional repression mechanisms of nucleolus organizer regions (NORs) in humans and chimpanzees. Chromosome Res., 12: 225-237.

Ha y fl i c k L. (1998). A brief history of the mortality and immortality of cultured cells. Keio J. Med., 47: 174-182.

Herbig U., F erreir a M., C on d e l L., C a re y D., S e div y J.M. (2006). Cellular senescence in aging primates. Science, 311, p. 1257.

Hin es W.C., F a jardo AM., Jos te N.E., B is offi M., Griffith J.K. (2005). Quantitative and 
spatial measurements of telomerase reverse transcriptase expression within normal and malignant human breast tissues. Mol. Cancer Res., 3: 503-509.

H o d e s R.J., H a th c o c k K.S., W e n g N.P. (2002). Telomeres in T and B cells. Nat. Rev. Immunol., 2: 699-706.

H u b be 11 H.R. (1985). Silver staining as an indicator of active ribosomal genes. Stain Technol., 60: 285-294.

H u d a N., T a n a k a H., H e r b e r t B.S., R e e d T., Gi 11 e y D. (2007). Shared environmental factors associated with telomere length maintenance in elderly male twins. Aging Cell., 6: 709-713.

Johnson T.E., Henderson S., Murakami S., de Castro E., de Castro S.H., Cyps e r J., R i k k e B., T e d e s c o P., L in k C. (2002). Longevity genes in the nematode Caenorhabditis elegans also mediate increased resistance to stress and prevent disease. J. Inherit. Metab. Dis., 25: 197-206.

J o h n s o n L.K., J o h n s on R., S tre hl er B.L. (1975). Cardiac hypertrophy, aging and changes in cardiac ribosomal RNA gene dosage in man. J. Mol. Cell Cardiol., 7: 125-133.

K a p p e i D., L on d o n o - V a 11 e j o J.A. (2008). Telomere length inheritance and aging. Mech. Ageing Dev., 129: 17-26.

Kos ciolek B.A., R ow ley P.T. (1998). Human lymphocyte telomerase is genetically regulated. Genes Chromosomes Cancer, 21: 124-130.

L e a ch N.T., R e h d e r C., Je n s e n K., Holt S., J a ck s o n-C o o k C. (2004). Human chromosomes with shorter telomeres and large heterochromatin regions have a higher frequency of acquired somatic cell aneuploidy. Mech. Ageing Dev., 125: 563-573.

L e vy M.Z., A 11 s o p p R.C., Futcher A.B., Greider C.W., Harley C.B. (1992). Telomere end-replication problem and cell aging. J. Mol. Biol., 225: 951-960.

Lezhava T. (2001). Chromosome and aging: genetic conception of aging. Biogerontology, 2: 253-260.

L i H., M it ch e 11 J.R., H a s t y P. (2008). DNA double-strand breaks: a potential causative factor for mammalian aging? Mech. Ageing Dev., 129: 416-424.

L i Y., S a n t o r o R., G r u m m t I. (2005). The chromatin remodeling complex NoRC controls replication timing of ribosomal RNA genes. EMBO J., 24: 120-127.

L i u L., W y li e R.C., A n d rew s L.G., T olle f s bol T.O. (2003). Aging, cancer and nutrition: the DNA methylation connection. Mech. Ageing Dev., 124: 989-998.

Matsubara Y., Murata M., Yoshida T., Watanabe K., Saito I., Miyaki K., $\mathrm{O}$ ma e K., I keda Y. (2006). Telomere length of normal leukocytes is affected by a functional polymorphism of hTERT. Biochem. Biophys. Res. Commun., 341: 128-131.

M a y s - H o o p e s L.L. (1989). DNA methylation in aging and cancer. J. Gerontol., 44: 35-36.

M c S t a y B., Grum m t I. (2008). The epigenetics of rRNA genes: from molecular to chromosome biology. Annu. Rev. Cell Dev. Biol., 24: 131-157.

Nakatan i K., Qu W.M., Zhang M.C., Fuji i H., F u rukaw a H., M i y a zaki T., I wa no M., S a i to Y., N o s e M., O n o M. (2007). A genetic locus controlling aging-sensitive regression of B lymphopoiesis in an autoimmune-prone MRL/lpr strain of mice. Scand. J. Immunol., 66: 654-661.

N a rit a M., N un ez S., H e ard E., N a rit a M., L in A.W., H e arn S.A., S pe c tor D.L., H a n n o n G.J., L o w e S.W. (2003). Rb-mediated heterochromatin formation and silencing of E2F target genes during cellular senescence. Cell, 113: 703-716.

Nordfjall K., O s t e r m a n P., M e l a n d er O., N il s s o n P., R o o s G. (2007). hTERT (-1327)T/ $\mathrm{C}$ polymorphism is not associated with age-related telomere attrition in peripheral blood. Biochem. Biophys. Res. Commun., 358: 215-218.

Nussenzweig A. (2007). Causes and consequences of the DNA damage response. Cell Cycle, 6: 2339-2340.

Sander M., Avlund K., Lauritzen M., Gottlieb T., Halliwell B., Stevnsner T., W e w e r U., Bohr V.A. (2008). Aging - from molecules to populations. Mech. Ageing Dev., 129: 614-623.

S e d e 1 n i k ova O.A., H or i k a w a I., Z i mon j i c D.B., P o pes c u N.C., B on n e r W.M., B a r re t t J.C. (2004). Senescing human cells and ageing mice accumulate DNA lesions with unrepairable double-strand breaks. Nat. Cell Biol., 6: 168-170. 
Sło t a E., Wnuk M., Bugno M., P i en kow ska - S chelling A., S chelling C., Bratus A., K o ty la k Z. (2007). The mechanisms determining the nucleolar-organizing regions inactivation of domestic horse chromosomes. J. Anim. Breed. Genet., 124: 163-171.

S mog or zew s ka A., d e L ange T. (2004). Regulation of telomerase by telomeric proteins. Annu. Rev. Biochem., 73: 177-208.

S t a n cheva I., L u c ch in i R., K o 11 er T., S o g o J.M. (1997). Chromatin structure and methylation of rat rRNA genes studied by formaldehyde fixation and psoralen cross-linking. Nucleic Acids Res., 25: 1727-1735.

Strohner R., Németh A., Nightingale K.P., Grummt I., B ecker P.B., Längst G. (2004). Recruitment of the nucleolar remodeling complex NoRC establishes ribosomal DNA silencing in chromatin. Mol. Cell. Biol., 24: 1791-1798.

Sw is she $1 \mathrm{~m}$ K., D is te che C.M., Thorvaldsen J., Nelson A., Salk D. (1990). Age-related increase in methylation of ribosomal genes and inactivation of chromosome-specific rRNA gene clusters in mouse. Mutat. Res., 237: 131-146.

Św itoński M., Marcolla P., P i énkowska A., Cholewiński G. (1994). Preliminary investigation on inter-individual variation of the nucleolar organizer regions (AgNORs) in the horse karyotype. Anim. Sci. Pap. Rep., 12: 15-19.

Th o m a s S., M u kher j e e A.B. (1996). A longitudinal study of human age-related ribosomal RNA gene activity as detected by silver-stained NORs. Mech. Ageing Dev., 92: 101-109.

U m J.H., K i m S.J., K i m D.W., H a M.Y., J ang J.H., K i m D.W., Chung B.S., Kang C.D., $\mathrm{K}$ i m S.H. (2003). Tissue-specific changes of DNA repair protein $\mathrm{Ku}$ and $\mathrm{mtHSP70}$ in aging rats and their retardation by caloric restriction. Mech. Ageing Dev., 124: 967-975.

W eng N.P., Levine B.L., J un e C.H., Hodes R.J. (1995). Human naive and memory T lymphocytes differ in telomeric length and replicative potential. Proc. Natl. Acad. Sci. U.S.A., 92: 11091-11094.

Wils on D.M., S of in ow ski T.M., McNeill D.R. (2003). Repair mechanisms for oxidative DNA damage. Front. Biosci., 8: 963-981.

Wnuk M., B u gno-P on i ew i erska M., Lew inska A., Oklejew i c z B., Zabek T., B ar tos z G., Słota E. (2011). Age-related changes in genomic stability of horses. Mech. Ageing Dev., 132: 257-268.

Zhang R., Chen W., A d a m s P.D. (2007). Molecular dissection of formation of senescence-associated heterochromatin foci. Mol. Cell Biol., 27: 2343-2358.

Accepted for printing 4 IV 2012

\title{
MACIEJ WNUK, MONIKA BUGNO-PONIEWIERSKA, ANNA LEWIŃSKA, BERNADETTA OKLEJEWICZ, TOMASZ ZĄBEK, EWA SŁOTA
}

\section{Proces starzenia się chromatyny u zwierząt}

\author{
STRESZCZENIE
}

Proces starzenia się jest zmiennym, stochastycznym i plejotropowym zjawiskiem, regulowanym przez różne czynniki środowiskowe i genetyczne. Zmiany związane z wiekiem, zachodzące na poziomach molekularnych i komórkowych, które zaburzają biologiczną homeostazę, mogą bezpośrednio lub pośrednio przyczyniać się do starzenia, wywołując apoptozę lub starzenie komórkowe, co w konsekwencji prowadzi do śmierci organizmu. W tym kontekście szczególnie interesujące są obserwacje zmian w chromatynie komórek somatycznych. W niniejszym artykule dokonano próby podsumowania wiedzy na temat biologicznych aspektów starzenia się, ze szczególnym uwzględnieniem związanych z wiekiem zmian w chromatynie, takich jak uszkodzenie DNA, skracanie telomerów lub związane z wiekiem zmiany w metylacji DNA. 